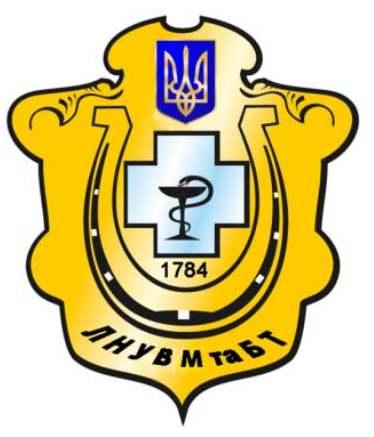

Науковий вісник Львівського національного університету ветеринарної медицини та біотехнологій імені С.3. Гжицького

Scientific Messenger of Lviv National University of Veterinary Medicine and Biotechnologies named after S.Z. Gzhytskyj

doi:10.15421/nvlvet6618

ISSN 2413-5550 print

ISSN 2518-1327 online

$\underline{\text { http://nvlvet.com.ua/ }}$

УДК 619:083.72:576.8.094.29

\title{
Таксономічна характеристика ДНК-геномних вірусів хребетних тварин і людини
}

\author{
О.С. Калініна \\ kalininaos@ukr.net \\ Львівський національний університет ветеринарної медицини та біотехнологій імені С.3. Гжицького, \\ вул. Пекарська, 50, м. Львів, 79010, Україна
}

Подано сучасну таксономію та номенклатуру ДНК-геномних вірусів хребетних тварин $і$ людини згідно з інформацією МКТВ випуску 2015 р. (ратифікаиія 2016 р.) Вказано провідні критерії класифікаиії вірусів: характеристика вірусного геному, механізм реплікації та морфологія віріонів. Віруси хребетних (1120 видів) входять у 4 порядки, 34 родини (12 ДНК-геномні, 22 - РНК-геномні), 11 підродин і 219 родів. ДНК-геномні віруси хребетних (546 видів) класифіковано в 1 порядок, 12 родин, 5 підродин і 113 родів. Порядок Herpesvirales об'єднує родини Herpesviridae та Alloherpesviridae. Родини Poxviridae, Iridoviridae i Parvoviridae, крім вірусів хребетних, містять віруси комах. Описано таксони вірусів: родини, підродини, роди, види. Названо типові види родів вірусів. Охарактеризовано основні таксономічні ознаки ДНК-геномних вірусів хребетних: форма, розміри і структура віріонів - наявність зовнішньої ліпопротеїнової оболонки, тип симетрії капсиду, структура вірусної ДНК, кількість білків. Акцентовано увагу на особливостях репродукиії вірусів. Реплікація більшості ДНК-геномних вірусів хребетних відбувається в ядрі клітин, за винятком представників родин Poxviridae ma Asfarviridae, які реплікуються в иитоплазмі. Вихід віріонів здійснюється внаслідок деструкиії клітин або брунькуванням через клітинні мембрани (іноді в поєднанні з екзоцитозом) залежно від структурної організачії вірусів.

Ключові слова: віруси, ДНК-геномні, родини, підродини, роди, види, типові, таксономічні ознаки.

\section{Таксономическая характеристика ДНК-геномных вирусов позвоноч- ных животных и человека}

\author{
О.С. Калинина \\ kalininaos@ukr.net
}

\begin{abstract}
Львовский национальный университет ветеринарной медицины и биотехнологий имени С.3. Гжицкого, ул. Пекарская, 50, г. Львов, 79010, Украина
\end{abstract}

\begin{abstract}
Представлена современная таксономия и номенклатура ДНК-геномных вирусов позвоночных животных и человека согласно с информацией МКТВ выпуска 2015 г. (ратификация 2016 г.). Указаны ведущие критерии классификаџии вирусов: характеристика вирусного генома, механизм репликачии и морфология вирионов. Вирусы позвоночных (1120 видов) входят в 4 порядка, 34 семейства (12 - ДНК-геномные, 22 - РНК-геномные), 11 подсемейств и 219 родов. ДНК-геномные вирусы позвоночных (546 видов) классифицированы в 1 порядок, 12 семейств, 5 подсемейств и 113 родов. Порядок Негреsvirales объединяет семейства Herpesviridae и Alloherpesviridae. Семейства Poxviridae, Iridoviridae и Parvoviridae, кроме вирусов позвоночных, содержат вирусы насекомых. Описаны таксоны вирусов: семейства, подсемейства, роды, виды. Охарактеризованы основные таксономические признаки ДНК-геномных вирусов позвоночных: форма, размеры и структура вирионов - наличие внешней липопротеиновой оболочки, тип симметрии капсида, структура вирусной ДНК, количество белков. Акиентировано внимание на особенностях репродукиии вирусов. Репликация большинства ДНК-геномных вирусов позвоночных происходит в ядре клеток, за исключением представителей семейств Рохviridae и Asfarviridae, которые реплицируются в ичитоплазме. Выход вирионов осуществляется вследствие деструкции клеток или почкованием через клеточные мембраны (иногда в сочетании с экзочитозом) в зависимости от структурной организации вирусов.
\end{abstract}

Ключевые слова: вирусы, ДНК-геномные, семейства, подсемейства, роды, виды, типовые, таксономические признаки.

\section{Citation:}

Kalinina, O.S. (2016). Taxonomic characteristics of DNA-genomic of viruses in vertebrates animals and human. Scientific Messenger LNUVMBT named after S.Z. Gzhytskyj, 18, 2(66), 83-87. 


\title{
Taxonomic characteristics of DNA-genomic of viruses in vertebrates animals and human
}

\author{
O.S. Kalinina \\ kalininaos@ukr.net

\begin{abstract}
Lviv National University of Veterinary Medicine and Biotechnologies named after S.Z. Gzhytskyi, Pekarska Str., 50, Lviv, 79010, Ukraine
\end{abstract}

\begin{abstract}
Presented modern taxonomy and nomenclature of the DNA-genomic of viruses of vertebrates animals and humans in accordance with the information ICTV release 2015 (ratification 2016). Described the basic criteria for the classification of viruses: characteristics of the viral genome, the mechanism of replication and virions morphology. Viruses of vertebrates (1120 species) consist of 4 orders, 34 families (12-DNA-genomic, 22 - RNA-genomic), 11 subfamilies and 219 genera. DNA-genomic viruses of vertebrates (546 species) classified in 1 orders, 12 families, 5 subfamilies and 113 genera. The order Herpesvirales has united family Herpesviridae and Alloherpesviridae. Family Poxviridae, Iridoviridae and Parvoviridae, except of viruses of vertebrates, contain viruses of insects. Described the taxa of viruses: family, subfamily, genera, species. Characterized the basic taxonomic features of DNAgenomic viruses of vertebrates: the shape, size and structure of virions - the presence of outer membrane lipoprotein, capsid symmetry type, the structure of the viral DN and the number of proteins. The attention is focused on the features of reproduction of viruses. The replication of majority DNA-genomic viruses of vertebrates occur in the nucleus of cells, except for members of families Poxviridae and Asfarviridae, which are replicate in the cytoplasm. Yield virions is done due to destruction of cells or budding through the cell membrane (sometimes in combination with exocytosis) depending on the structural organization of the virus.
\end{abstract}

Key words: viruses, DNA-genomic, family, subfamily, genera, species, type, taxonomic features.

Сучасна класифікація вірусів є універсальною для вірусів хребетних, безхребетних, рослин, грибів, найпростіших і бактерій. Вона грунтується на фундаментальних властивостях вірусів, 3 яких провідними $є$ ознаки, що характеризують нуклеїнову кислоту, механізм реплікації та морфологію віріонів (Kalinina et al., 2015; Kalinina, 2016). Віруси хребетних (1120 видів) входять у 4 порядки, 34 родини (12 - ДНКгеномні, 22 - РНК-геномні), 11 підродин і 219 родів. ДНК-геномні віруси хребетних тварин і людини (546 видів) класифіковано в порядок Herpesvirales (об'єднує родини Herpesviridae та Alloherpesviridae), 12 родин, 5 підродин і 113 родів (Kalinina et al., 2015; Kalinina, 2016). Родини Poxviridae, Iridoviridae i Parvoviridae, крім вірусів хребетних, містять віруси комах. ДНК-геномним вірусам, незалежно від складності структурної організації, властивий ікосаедральний тип симетрії капсиду. Виняток становлять представники родини Poxviridae, які мають порівняно 3 іншими вірусами нетрадиційну будову (Kalinina et al., 2015; Kalinina, 2016). Таксономічна характеристика ДНК-геномних вірусів хребетних тварин і людини подана згідно з інформацією Міжнародного комітету 3 таксономії вірусів (МКТВ) випуску 2015 р. (ратифікація 2016 р.).

Родина Poxviridae (поксвіруси) - 1 підродина, 10 родів, 38 видів.

Підродина Chordopoxvirinae (10 родів) 1. Рід Avipoxvirus (10 видів): віруси віспи курей*, індиків, голубів, перепілок, канарок, горобців, шпаків, папуг, юнко, майн. 2. Рід Capripoxvirus (3 види): віруси віспи овець*, кіз, вірус нодулярного дерматиту ВРХ. 3. Рід Cervidpoxvirus (1 вид): вірус віспи мулів та оленів*. 4. Рід Crocodylidpoxvirus (1 вид): вірус віспи нільських крокодилів*. 5. Рід Leporipoxvirus (4 види): віруси міксоми*, фіброми кролів, зайців, білок. 6. Рід Molluscipoxvirus (1 вид): вірус контагіозного молюска*. 7. Рід Orthopoxvirus (10 видів): віруси вісповак-

\footnotetext{
*Типовий вид.
}

цини*, натуральної віспи, віспи корів, верблюдів, мавп, єнотів, скунсів, африканських піщанок, полівок, вірус ектромелії. 8. Рід Parapoxvirus (4 види): віруси орф*, псевдовіспи корів, папульозного стоматиту ВРX, парапоксвірус новозеландських благородних оленів. 9. Рід Suipoxvirus (1 вид): вірус віспи свиней*. 10. Рід Yatapoxvirus (2 види): віруси пухлин мавп Яба*, віспи Тана. Некласифікований вірус: вірус віспи білок.

Основні ознаки. Віріони більшості поксвірусів хребетних мають форми цеглини із заокругленими кутами, розміром $(300 \ldots 450) \times(170 \ldots 260)$ нм. Виняток становлять представники роду Parapoxvirus, віріони яких овоїдної форми, розміром $(220 \ldots 300) \times(140 \ldots 170)$ нм, і роду Molluscipoxvirus овоїдної або молюскоподібної форми, розміром $320 \times 250$ нм. Структура: 1) зовнішня оболонка (з трубчастими ворсинками); 2) серцевина (у вигляді двовгнутого диска); 3) зовнішній шар із циліндричних субодиниць; 4) внутрішня гладка мембрана; 5) дволанцюгова ДНК; 6) латеральні тіла; 7) 100 білків, у т. ч. ДНК-залежна РНК-полімераза (транскриптаза). Реплікація та складання віріонів відбуваються в цитоплазмі. Віріони транспортуються до плазмолеми через комплекс Гольджі та виходять із клітини шляхом екзоцитозу або після іiі лізису.

Родина Asfarviridae (асфарвіруси) - 1 рід, 1 вид.

Рід Asfivirus (1 вид): вірус африканської чуми свиней*.

Основні ознаки. Віріони ікосаедральної форми, діаметр 175-215 нм. Структура: 1) зовнішня ліпопротеїнова оболонка; 2) ікосаедральний нуклеокапсид; 3) дволанцюгова ДНК; 4) 34 білки, у т. ч. ДНК-залежна РНК-полімераза (транскриптаза). Реплікація відбувається в цитоплазмі, а складання і вихід віріонів із клітини - брунькуванням через плазмолему.

Родина Iridoviridae (ірідовіруси) - 3 роди, 8 видів.

1. Рід Lymphocystivirus (1 вид): вірус лімфоцистозу 1*. 2. Рід Megalocytivirus (1 вид): вірус інфекційного некрозу селезінки і нирок*. 3. Рід Ranavirus (6 видів): 
віруси жаб $3 *$, тигрових амбістом, епізоотичного гематопоетичного некрозу, європейських сомів, ранавірус Санті-Купер, ірідовірус водних рептилій.

Основні ознаки. Віріони сферичної форми, діаметром 130-300 нм. Структура: 1) зовнішня ліпопротеїнова оболонка; 2) ікосаедральний нуклеокапсид; 3) дволанцюгова ДНК; 4) понад 20 білків, у т. ч. ДНКзалежна РНК-полімераза (транскриптаза). Реплікація відбувається в цитоплазмі, а складання і вихід віріонів iз клітини - брунькуванням через плазмолему.

\section{Родина Herpesviridae (герпесвіруси)}

3підродини, 13 родів, 86 видів.

I. Підродина Alphaherpesvirinae (5 родів) 1. Рід Itovirus (2 види): альфагерпесвіруси куриних $1 *$, папуг 1. 2. Рід Mardivirus (5 видів): альфагерпесвіруси куриних $2 *, 3$, качиних 1, індиків 1, голубиних 1. 3. Рід Scutavirus (1 вид): альфагерпесвірус морських черепах 5*. 4. Рід Simplexvirus (12 видів): альфагерпесвіруси людини $1 *, 2$, великої рогатої худоби 2 , кролів 4, павукоподібних мавп 1, макак 1 , церкопітекових мавп 2, білячих мавп 1, павіанів 2, кенгуру 1, 2, шимпанзе 3. 5. Рід Varicellovirus (17 видів): альфагерпесвіруси людини $3 *$, великої рогатої худоби 1,5 , кіз 1 , коней 1 , $3,4,8,9$, свиней 1 , буйволів 1 , оленів 1,2 , собак 1 , котів 1, церкопітекових мавп 9, тюленів 1. Некласифікований вірус: альфагерпесвірус морських черепах 6.

II. Підродина Bethaherpesvirinae (4 роди) 1. Рід Cytomegalovirus (8 видів): бетагерпесвіруси людини $5^{*}$, нічних мавп 1 , капуцинових мавп 1 , церкопітекових мавп 5, макак 3, шимпанзе 2, павіанів 3, білячих мавп 4. 2. Рід Muromegalovirus (3 види): бетагерпесвіруси мишей 1*, 2, 8. 3. Рід Proboscivirus (1 вид): бетагерпесвірус слонів*. 4. Рід Roseolovirus (3 види): бетагерпесвіруси людини 6А*, 6В, 7. Некласифіковані віруси (3 види): бетагерпесвіруси свиней 2, морських свинок 2 , тупай 1 .

III. Підродина Gammaherpesvirinae (4 роди) 1. Рід Limphocryptovirus (8 видів): гаммагерпесвіруси людини $4 *$, шимпанзе 1 , павіанів 1 , макак 4, орангутангів 2 , церкопітекових мавп 14, горил 1, мармозетів 3. 2. Рід Macavirus (9 видів): гаммагерпесвіруси коров'ячих антилоп $1 *, 2$, конячих антилоп 1 , великої рогатої худоби 6, овець 2, кіз 2, свиней 3, 4, 5. 3. Рід Percavirus (3 види): гаммагерпесвіруси коней $2 *, 5$, куницевих 1. 4. Рід Rhadinovirus (9 видів): гаммагерпесвіруси білячих мавп $2 *$, людини 8 , павукоподібних мавп 2, 3, макак 5, церкопітекових мавп 17, ВРX 4, мишей 4, 7. Некласифікований вірус у родині: герпесвірус ігуан 2.

Основні ознаки. Віріони сферичної форми, діаметром 85-300 нм. Структура: 1) зовнішня ліпопротеїнова оболонка (з пепломерами); 2) тегумент; 3) ікосаедральний капсид (162 капсомери); 4) серцевина; 5) дволанцюгова ДНК; 6) 20-32 білки. Реплікація відбувається в ядрі, а складання віріонів - брунькуванням через ядерну мембрану. Віріони виходять із клітини шляхом екзоцитозу, транспортуючись у цитоплазматичних вакуолях, які зливаються з плазмолемою.

Родина Alloherpesviridae (аллогерпесвіруси) - 4 роди, 12 видів.

1. Рід Batrachovirus (2 види): герпесвіруси жаб 1*, 2. 2. Рід Cyprinivirus (4 види): герпесвіруси коропових 3*, 1, 2, вугрів 1. 3. Рід Ictalurivirus (3 види): герпесві- руси канальних сомиків $1^{*}, 2$, осетрових 2. 4. Рід Salmonivirus (3 види): герпесвіруси лососевих 1*, 2, 3.

Основні ознаки. Віріони сферичної форми, діаметром 150-200 нм. Структура: 1) зовнішня ліпопротеїнова оболонка (з пепломерами); 2) тегумент; 3) ікосаедральний капсид (162 капсомери); 4) серцевина; 5) дволанцюгова ДНК; 6) понад 20 білків. Транскрипція та реплікація вірусного геному відбуваються в ядрі, а складання віріонів - брунькуванням через ядерну мембрану й остаточно - через мембрани комплексу Гольджі. Віріони виходять із клітини шляхом екзоцитозу.

Родина Adenoviridae (аденовіруси) - 5 родів, 50 видів.

1. Рід Atadenovirus (5 видів): атаденовіруси овець $\mathrm{D}^{*}$, великої рогатої худоби $\mathrm{D}$, качок А, опосумів А, змій А. 2. Рід Aviadenovirus (12 видів): авіаденовіруси курей $\mathrm{A}^{*}, \mathrm{~B}, \mathrm{C}, \mathrm{D}, \mathrm{E}$, гусей $\mathrm{A}$, качок В, індиків В, C, D, голубів A, соколів А. 3. Рід Ichtadenovirus (1 вид): іхтаденовірус осетрових А*. 4. Рід Mastadenovirus (27 видів): мастаденовіруси людини $\mathrm{C}^{*}, \mathrm{~A}, \mathrm{~B}, \mathrm{D}, \mathrm{E}, \mathrm{F}, \mathrm{G}$, великої рогатої худоби $\mathrm{A}, \mathrm{B}, \mathrm{C}$, овець $\mathrm{A}, \mathrm{B}$, свиней $\mathrm{A}$, В, С, коней А, В, собак А, мавп А, В, С, кажанів А, В, мишей А, В, С, землерийок 1. 5. Рід Siadenovirus (5 видів): сіаденовіруси жаб А*, індиків А, великих синиць А, хижих птахів А, південно-полярних поморників А.

Основні ознаки. Віріони ікосаедральної форми, діаметром 70-90 нм. Структура: 1) ікосаедральний капсид (252 капсомери, вершинні капсомери утворюють 12 фібрил); 2) серцевина; 3) дволанцюгова ДНК; 4) 10-14 білків. Реплікація та складання віріонів відбуваються в ядрі, а вихід віріонів із клітини - внаслідок їі деструкції.

Родина Papillomaviridae (папіломавіруси) - 49 родів, 116 видів.

1. Рід Alphapapillomavirus (14 видів): альфапапіломавіруси $1 *, 2,3,4,5,6,7,8,9,10,11,12,13,14.2$. Рід Betapapillomavirus (6 видів): бетапапіломавіруси $1^{*}, 2$, 3, 4, 5, 6. 3. Рід Chipapillomavirus (3 види): чіпапіломавіруси $1 *, 2,3$. 4. Рід Deltapapillomavirus (6 видів): дельтапапіломавіруси $1 *, 2,3,4,5,6$. 5. Рід Dyochipapillomavirus (1 вид): диочіпапіломавірус 1. 6. Рід Dyodeltapapillomavirus (1 вид): диодельтапапіломавірус 1*. 7. Рід Dyoepsilonpapillomavirus (1 вид): диоепсілонпапіломавірус $1 *$. 8. Рід Dyoetapapillomavirus (1 вид): диоетапапіломавірус 1. 9. Рід Dyoiotapapillomavirus (2 види): диоіотапапіломавіруси 1*, 2. 10. Рід Dyokappapapillomavirus (2 види): диокаппапапіломавіруси $1 *$, 2. 11. Рід Dyolambdapapillomavirus (1 вид): диолямбдапапіломавірус $1 *$ 12. Рід Dyomupapillomavirus (1 вид): диомупапіломавірус $1 *$. 13. Рід Dyonupapillomavirus (1 вид): дионупапіломавірус 1*. 14. Рід Dyoomegapapillomavirus (1 вид): диоомегапіломавірус $1^{*}$. 15. Рід Dyoomikronpapillomavirus (1 вид): диоомікронпапіломавірус $1 *$ 16. Рід Dyophipapillomavirus (1 вид): диофіпапіломавірус $1 *$. 17. Рід Dyopipapillomavirus (1 вид): диопіпапіломавіpyc 1*. 18. Рід Dyopsipapillomavirus (1 вид): диопсіпіломавірус 1*. 19. Рід Dyorhopapillomavirus (1 вид): диоропапіломавірус 1*. 20. Рід Dyosigmapapillomavirus (1 вид): диосігмапапіломавірус 1*. 21. Рід Dyotaupapillomavirus (1 вид): диотаупапіломавірус $1 *$. 
22. Рід Dyothetapapillomavirus (1 вид): диотетапапіломавірус 1*. 23. Рід Dyoupsilonpapillomavirus (1 вид): диоупсилонпапіломавірус 1*. 24. Рід Dyoxipapillomavirus (1 вид): диоксіпапіломавірус 1*. 25. Рід Dyozetapapillomavirus (1 вид): диозетапапіломавірус 1*. 26. Рід Epsilonpapillomavirus (1 вид): епсілонпапіломавірус 1*. 27. Рід Etapapillomavirus (1 вид): етапапіломавірус 1*. 28. Рід Gammapapillomavirus (26 видів): гаммапапіломавіруси $1 *, 2,3,4,5,6,7,8,9,10$, $11,12,13,14,15,16,17,18,19,20,21,22,23,24,25$, 26. 29. Рід Iotapapillomavirus (1 вид): іотапапіломавіpус $1 *$. 30. Рід Kappapapillomavirus (2 види): каппапапіломавіруси $2 *$, 1. 31. Рід Lambdapapillomavirus (5 видів): лямбдапапіломавіруси 2*, 1, 3, 4, 5. 32. Рід Mupapillomavirus (3 види): мупапіломавіруси $1 *$, 2. 3. 33. Рід Nupapillomavirus (1 вид): нупапіломавірус $1 *$ 34. Рід Omegapapillomavirus (1 вид): омегапапіломавірус 1*. 35. Рід Omikronpapillomavirus (1 вид): омікропапіломавірус 1*. 36. Рід Phipapillomavirus (1 вид): фіпапіломавірус 1*. 37. Рід Pipapillomavirus (2 види): піпапіломавіруси $1 *$, 2. 38. Рід Psipapillomavirus (1 вид): псіпапіломавірус 1*. 39. Рід Rhopapillomavirus (2 види): ропапіломавіруси $1 *$, 2. 40. Рід Sigmapapillomavirus (1 вид): сігмапапіломавірус 1*. 41. Рід Taupapillomavirus (3 види): таупапіломавіруси 1*, 2, 3 . 42. Рід Thetapapillomavirus (1 вид): тетапапіломавірус 1*. 43. Рід Treisdeltapapillomavirus (1 вид): трайсдельтапапіломавірус 1*. 44. Рід Treisepsilonpapillomavirus (1 вид): трайсепсілонпапіломавірус $1 *$ 45. Рід Treisetapapillomavirus (1 вид): трайсетапапіломавірус $1 *$. 46. Рід Treiszetapapillomavirus (1 вид): трайзетапапіломавірус 1*. 47. Рід Upsilonpapillomavirus (3 види): упсілопапіломавіруси $1 *, 2,3.48$. Рід Хipapillomavirus (3 види): ксіпапіломавіруси $1 *, 2,3.49$. Рід Zetapapillomavirus (1 вид): зетапапіломавірус $1 *$.

Основні ознаки. Віріони ікосаедральної форми, діаметром 55 нм. Структура: 1) ікосаедральний капсид (72 капсомери); 2) дволанцюгова кільцева ДНК; 3) 2 білки. Реплікація та складання віріонів відбуваються в ядрі, а вихід віріонів із клітини - внаслідок іiі деструкції.

Родина Polyomaviridae (поліомавіруси) - 4 роди, 76 видів.

1. Рід Alphapolyomavirus (36 видів): поліомавіруси хатніх мишей $1^{*}$, сірійських хом'ячків, людини $5,8,9$, 12,13 , африканських зелених мавп 1,3 , червонолицих коат 1 , західних горил 1 , крабоїдних макак 1 , звичайних шимпанзе $1,2,3,4,5,6,7$, бабуїнів 1 , танських червоних колобусів 1, суматранських орангутанів 1 , калімантанських орангутанів 1, північних єнотів 1, целебеських ацеродонів 1, плосколицих листконосів 2,3 , жовтоплечих листконосів 1, африканських несправжніх вампірів 1, очкових листконосів 1, молукських голоспинних криланів 1, малайських криланів 1 , пальмових криланів 1, звичайних молосів 1, широковухих складчастогубів 1, 2. 2. Рід Betapolyomavirus (26 видів): поліомавіруси макак-резусів $1^{*}$, людини 1 , $2,3,4$, білолобих капуцинів 1 , рудовухих мавп 1 , африканських зелених мавп 2, болівійських саймірі 1 , білячих мавп 1 , бабуїнів 2, свійських коней 1 , борсуків 1, саванних слонів 1, натальських мишей 1, звичайних вампірів 1, молукських голоспинних криланів 2, 3, целебеських ацеродонів 2, плосколицих листко- носів 1, африканських довгокрилів 1, хатніх мишей 2 , малих бурих нічниць 1 , листконосів Деві 1, голоспинних листконосів 1, каліфорнійських морських левів 1 . 3. Рід Deltapolyomavirus (4 види): поліомавіруси людини 6*, 7, 10, 11. 4. Рід Gammapolyomavirus (7 видів): поліомавіруси птахів $1^{*}$, сірих гусей 1 , галок 1 , сіроспинних флейтових птахів 1, пінгвінів Аделі 1, снігурів 1, канарок 1. Некласифіковані віруси (3 види): поліомавіруси свійських биків 1, чорних морських окунів 1 , звичайних дельфінів.

Основні ознаки. Віріони ікосаедральної форми, діаметром 40-45 нм. Структура: 1) ікосаедральний капсид (72 капсомери); 2) дволанцюгова кільцева ДНК; 3) 3 білки. Реплікація та складання віріонів відбуваються в ядрі, а вихід віріонів із клітини - внаслідок іï деструкції. 9 видів.

Родина Hepadnaviridae (гепаднавіруси) - 2 роди,

1. Рід Avihepadnavirus (2 види): віруси гепатиту В качок*, чапель. 2. Рід Orthohepadnavirus (7 видів): віруси гепатиту В*, гепатиту В довгопалих нічниць, гімалайских листконосів, листконосів-будівників, шерстистих мавп, гепатиту бабаків.

Основні ознаки. Віріони сферичної форми, діаметром 42 нм. Структура: 1) зовнішня ліпопротеїнова оболонка; 2) ікосаедральний нуклеокапсид (серцевина); 3) дволанцюгова кільцева ДНК (із дефектом плюс-нитки на 20-50\%); 4) 6 білків, у т. ч. ДНКзалежна ДНК-полімераза. Реплікація та складання серцевини віріонів відбуваються в ядрі. Віріони формуються брунькуванням через мембрани ендоплазматичної сітки і виходять із клітини шляхом екзоцитозу.

Родина Parvoviridae (парвовіруси) - 1 підродина, 8 родів, 41 вид.

Підродина Parvovirinae (8 родів) 1. Рід Amdoparvovirus (2 види): амдопарвовірус м'ясоїдних 1*, 2. 2. Рід Aveparvovirus (1 вид): авепарвовірус куриних 1*. 3. Рід Bocaparvovirus (12 видів): бокапарвовіруси копитних $1 *, 2,3,4,5$, м'ясоїдних $1,2,3$, ластоногих 1, 2, приматів 1, 2. 4. Рід Copiparvovirus (2 види): копіпарвовіруси копитних $1 *$, 2. 5. Рід Dependoparvovirus (7 видів): аденоасоційовані депендопарвовіруси $\mathrm{A}^{*}, \mathrm{~B}$, депендопарвовіруси птахів 1, гусей 1 , рукокрилих 1 , ластоногих 1 , лускатих 1. 6. Рід Erythroparvovirus (6 видів): еритропарвовіруси приматів $1 *, 2,3,4$, гризунів 1, копитних 1. 7. Рід Protoparvovirus (5 видів): протопарвовіруси гризунів $1 *, 2$, копитних 1, м'ясоїдних 1, приматів 1. 8. Рід Tetraparvovirus (6 видів): тетрапарвовіруси приматів $1^{*}$, копитних $1,2,3,4$, рукокрилих 1 .

Основні ознаки. Віріони ікосаедральної форми, діаметром 18-26 нм. Структура: 1) ікосаедральний капсид (32 капсомери); 2) одноланцюгова ДНК (мінус- або плюс-нитка); 3) 3-4 білки. Реплікація та складання віріонів відбуваються в ядрі, а вихід віріонів із клітини - внаслідок їі деструкції.

Родина Circoviridae (цирковіруси) - 2 роди, 41 вид.

1. Рід Circovirus (22 види): цирковіруси свиней 1 *, 2, собак, норок, кажанів 1, 2, 3, марен, європейських сомів, качок, гусей, канарок, голубів, круків, шпаків, лебедів, чайок, зябликів, зебрових амадин, хвороби 
дзьоба і пір'я, асоційовані із фекаліями цирковіруси людини, шимпанзе. 2. Рід Cyclovirus (19 видів): цикловіруси людини $1 *, 2,3, \mathrm{BPX}$, кіз, курей, кажанів, асоційовані з фекаліями цикловіруси людини $1,2,3$, $4,5,6,8$, шимпанзе, кажанів 1, 2, 3, 4 .

Основні ознаки. Віріони ікосаедральної форми, діаметром 15-25 нм. Структура: 1) ікосаедральний капсид (32 капсомери); 2) одноланцюгова кільцева ДНК (мінус-нитка); 3) 1 білок. Реплікація та складання віріонів відбуваються в ядрі, а вихід віріонів із клітини - внаслідок її деструкції.

Родина Anelloviridae (анелловіруси) - 12 родів, 68 видів.

1. Рід Alphatorquevirus (29 видів): віруси тонкого намиста $1 * 2,3,4,5,6,7,8,9,10,11,12,13,14,15$, 16, 17, 18, 19, 20, 21, 22, 23, 24, 25, 26, 27, 28, 29. 2. Рід Betatorquevirus (12 видів): віруси маленького тонкого намиста $1 *, 2,3,4,5,6,7,8,9,10,11,12$. 3. Рід Deltatorquevirus (1 вид): вірус тонкого намиста тупай*. 4. Рід Epsilontorquevirus (1 вид): вірус тонкого намиста тамаринів. 5. Рід Etatorquevirus (2 види): віруси тонкого намиста котів*, 2. 6. Рід Gammatorquevirus (15 видів): віруси проміжного тонкого намиста $1 *, 2,3,4,5,6,7,8,9,10,11,12,13,14$, 15. 7. Рід Gyrovirus (1 вид): вірус анемії курчат*. 8. Рід Iotatorquevirus (2 види): віруси тонкого намиста свиней 1a*, 1b. 9. Рід Kappatorquevirus (2 види): віруси тонкого намиста свиней k2a*, k2b. 10. Рід
Lambdatorquevirus (1 вид): вірус тонкого намиста каліфорнійських морських левів 1*. 11. Рід Thetatorquevirus (1 вид): вірус тонкого намиста собак 1 * 12. Рід Zetatorquevirus (1 вид): вірус тонкого намиста нічних мавп $1 *$.

Основні ознаки. Віріони ікосаедральної форми, діаметром 30-32 нм. Структура: 1) ікосаедральний капсид; 2) одноланцюгова кільцева ДНК (мінуснитка); 3) 2-4 білки. Реплікація та складання віріонів відбуваються в ядрі, а вихід віріонів із клітини - внаслідок ії деструкції.

Висновки. 546 видів ДНК-геномних вірусів хребетних тварин і людини класифіковано в 1 порядок, 12 родин, 5 підродин і 113 родів. МКТВ поступово запроваджує бінарну номенклатуру у видових назвах вірусів.

\section{Бібліографічні посилання}

Kalinina, O.S. (2016). Klasyfikacija ta nomenklatura virusiv tvaryn i ljudyny. - L'viv: LNUVMtaBT imeni S.Z. G'zhyc'kogo (in Ukrainian).

Kalinina, O.S., Panikar, I.I., Skybic'kyj, V.G. (2015). Rozdil 3. Klasyfikacija i nomenklatura virusiv / Veterynarna virusologija: Pidruchnyk. 2-ge vyd., pererob. i dop. Kyi'v: Nichlava, 41-71 (in Ukrainian).

Стаття надійшла до редакиії 15.09.2016 